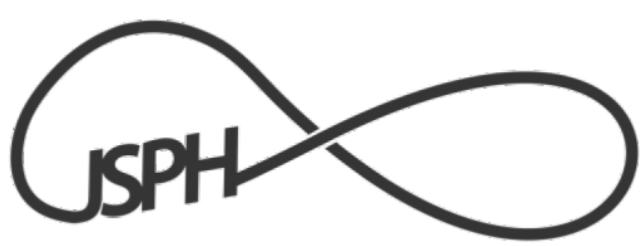

Jurnal Sosiologi Pendidikan Humanis
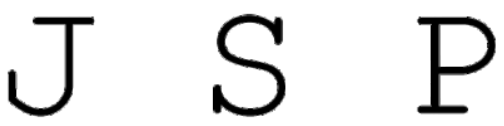

Jurnal Sosiologi Pendidikan Humanis Volume 1, Nomor 2, Desember 2016, Halaman 103 - 116

E-ISSN 2527-5879 P-ISSN 2527-5879

http://journal.um.ac.id/index.php/jsph

\title{
PENDIDIKAN POLITIK DALAM KUASA SIMBOLIK \\ KAJIAN MENGENAI DINAMIKA POLITIK ANAK MUDA \\ YANG TERGABUNG DALAM PARTAI POLITIK DI KOTA MALANG
}

\author{
Nanda Harda P.M. \\ Jurusan Sosiologi Universitas Negeri Malang \\ Email: nanda.harda.fis@um.ac.id
}

\begin{abstract}
Abstrak
Saat ini dunia perpolitikan kerap memperoleh stigma negatif akibat tindakan-tindakan oknum kader di dalamnya. Maka tak heran apabila masyarakat terutama kaum muda makin apatis dengan hal-hal yang berbau politis. Namun rupanya masih ada anak-anak muda yang masih memiliki kepedulian bahkan bergabung dengan partai politik. Pun demikian di Kota Malang dimana salah satu partai politik memiliki cukup banyak kader muda. Bahkan beberapa di antara mereka berhasil untuk masuk daftar calon legislatif pada Pemilu 2014 lalu. Menggunakan metode kualitatif dengan pendekatan biografi digunakan untuk memperoleh data dan menganalisa keterlibatan anak-anak muda tersebut dalam dunia politik. Terutama terkait pendidikan politik yang didapatkan mereka selama di partai. Menggunakan model purposive, pemilihan informan dalam penelitian kali ini lebih menitikberakan pada anak muda yang bergelut di dalam dunia politik. Namun rupanya masih terdapat ketimpangan yang anak-anak muda tersebut rasakan selama berada di partai. Masih terdapat kesenjangan antara mereka yang senior dan yang muda. Hal tersebut yang kemudian memunculkan kekerasan simbolik pada anak-anak muda tersebut. Terlebih di dalam tubuh partai politik dimana kerap kali sering muncul perebutan kekuasaan antar elit. Sementara mereka yang muda hanya menjadi pendukung atau bahkan penonton semata.
\end{abstract}

Kata Kunci : Media Massa, Kekerasan Simbolik, Stereotipe

\section{POLITICAL EDUCATION UNDER SYMBOLIC POWER \\ THE STUDY ABOUT POLITICAL DYNAMICS OF YOUTH WHO JOIN POLITICAL PARTY IN MALANG}

\begin{abstract}
Now days politics sometime have negative stigma from the actions of the people who join inside the political parties. Then no wonder if the society especially youth become more apathetic with something which related with politics. But there is some youth who have political awareness and also join political parties. That also happen in Malang where have one political party that youth joined and even became legislative candidates for 2014 election. Using qualitative methods and biography approach, the researcher collected the data and also analyzed the involvement of the youth who join into political party, especially about political education. Using purposive design to get the information, the informants for this research are youth who join political party. However there is still imbalance between older generation and younger generation. That bring out symbolic violence to the youth because of their limitation of capital that they owned. Political party become a place to struggle between political elite, while youth just become spectator only.
\end{abstract}

Kata Kunci : Media Massa, Kekerasan Simbolik, Stereotipe 


\section{LATAR BELAKANG}

Dalam konteks sejarah sosial dan politik di Indonesia, anak muda mampu menempatkan diri dalam perjuangan bangsa. Hal tersebut dapat disaksikan pada konteks para tokoh-tokoh revolusi bangsa seperti Soekarno, Hatta, Syahrir, ataupun Tan Malaka yang telah memulai karir perpolitikannya sejak usia muda. Bahkan pada tahun 1928 tercetuslah ide-ide kebangsaan yang digawangi oleh para pemuda yang berasal dari berbagai daerah di hampir seluruh pelosok nusantara melalui Sumpah Pemuda. Tak ayal bahwa pemuda menjadi salah satu akar dalam ranah perpolitikan bangsa bahkan hingga saat ini dimana mereka memiliki andil yang besar sebagai generasi penerus bangsa.

Tidak hanya sekali namun terulang dalam beberapa kali peristiwa sejarah kebangsaan dimana para pemuda menjadi aktor-aktor penting di dalamnya. Setidaknya terdapat 3 peristiwa penting paska Sumpah Pemuda 1928 dimana para pemuda turut andil yakni pada Proklamasi kemerdekaan Indonesia 1945 dan dua kali pada masa pergantian rezim di tahun 1965 dan 1998. Dalam peristiwa tersebut tidak dapat dipungkiri bahwa mereka para kaum muda menjadi salah satu motor gerakan yang masif dalam melakukan sebuah perubahan sosial (Anderson,1988; Ricklef,2008). Para pemuda memiliki andil dalam setiap lahirnya sebuah era di Indonesia. Layaknya sebuah siklus dimana kaum muda menjadi agen-agen perubahan politik bagi bangsanya.

Pemuda bukan hanya sekedar permasalahan status biologis tapi juga terdapat aspek-aspek sosial yang melekat di dalamnya (Mannheim,1952). Hal tersebut berusaha ditekankan oleh Mannheim bahwasanya konteks usia pada pemuda bukanlah sesuatu yang harus dianggap dominan. Oleh sebab itu pemuda tidak kemudian hanya dilihat dari segi usia semata. Terlebih lagi karena aspek-aspek tersebut pula pemuda kerap disisihkan karena dianggap tidak memiliki pengalaman atau andil di dalam kehidupan bermasyarakat. Namun sejarah masih merekam bahwasanya mereka yang berada dalam usia muda justru menjadi salah satu motor pergerakan nasional.

Pada masa paska reformasi dimana era keterbukaan dan partisipasi publik lebih "bebas", pola dinamika politik tidak hanya dilakukan di pusaran partai politik namun juga pada tataran institusi pendidikan. Hal tersebut dapat kita lihat dari pola dan dinamika politik kaum muda yang saling bersaing melalui organisasi kemahasiswaan atau gerakan di dalamnya (terutama pada tataran perguruan tinggi). Tidak hanya sebatas di dalam gerakan organisasi kemahasiswaan, tidak jarang dari mereka yang turut andil langsung dalam partai politik. Walaupun demikian tentunya mereka juga merupakan generasi yang sesuai dengan zamannya dimana konsumsi dan teknologi mejadi salah satu bagian yang tidak lepas dalam kehidupannya, termasuk di partai politik (Parker and Nilan,2013).

Meskipun banyak terdapat potret buram di dalam dunia perpolitikan Indonesia, namun rupanya partai politik tetap memiliki daya tarik tersendiri bagi para anak muda. Tentunya menjadi sebuah kesempatan sekaligus peluang bagi para anak muda tersebut untuk masuk dan mengaktualisasikan diri di dalam partai politik. Sebagaimana diketahui dalam era demokrasi seperti saat ini, partai politik menjadi salah . 
satu aspek dominan. Richard Katz bahkan menyebutkan"modern democracy is party democracy" (dalam Marijan, 2012). Partai politik menjadi penghubung antara penguasa (pemerintah) dan juga masyarakat (konstituen). Hal tersebut juga dapat dilihat dalam tulisan mengenai integrasi penguatan partai politik di Kota Malang (Salviana, 2015).

Bergabungnya para anak-anak muda pada partai politik tentunya menjadi sebuah harapan terkait partisipasi langsung mereka dalam dunia politik. Partai politik juga tentunya mendapatkan suntikan tenaga baru yang masih segar sebagai bagian dari proses regenerasi di tubuh partai. Maka tak heran proses demoratisasi yang selama ini kerap dianggap stagnan karena kurang memunculkan generasi muda, perlahan mulai bermunculan kaum muda yang tergabung dalam partai, termasuk di Kota Malang. Sebagai salah satu kota besar yang memiliki proporsi pemuda (di bawah usia 30 tahun) mencapai 33\%, rupanya partai politik juga memiliki pengaruh yang cukup kuat terutama dalam melakukan kaderisasi di ranah grass-root.

Layaknya dinamika perpolitikan di tingkat nasional, Kota Malang juga memiliki banyak kisah tentang dunia perpolitikan terutama terkait pilkada hingga pilpres. Penelitian pada kali ini mengambil salah satu partai politik besar di wilayah Kota Malang sebagai kajian. Hal ini melihat cukup kuatnya posisi partai tersebut di wilayah Kota Malang sejak paska reformasi hingga saat pemilu legislatif 2014 kemarin. Selain mengabil fokus pada dinamika anak-anak muda di dalam partai tersebut, penelitian ini berusaha melihat pendidikan politik di dalamnya. Tidak hanya itu, penelitian ini juga menyingkap kuasa simbolik yang dialami oleh para anak-anak muda tersebut selama tergabung di dalam partai politik.

\section{METODE PENELITIAN}

Sebelumnya peneliti berusaha menggunakan padanan kata lain dari pemuda dengan anak muda. Hal ini karena pada kondisi di lapangan, rupanya tidak sama dengan definisi pemuda menurut UU nomor 40 tahun 2009 dimana pemuda merupakan mereka yang berada pada usia 16-30 tahun. Sementara di lapangan bahwa pemuda bisa berusia hingga 40 tahunan. Bahkan salah satu kader yang memegang jabatan pada bidang kaderisasi telah berumur lanjut. Hal tersebut karena dari informasi baik elit maupun kader partai mengungkapkan bahwa beberapa anggoi . yang menurut mereka muda, sering kali melebihi usia yang didefinisikan pemuda oleh Negara. Jadi di dalam tubuh masing-masing partai juga memiliki perbedaan dalam mendefinisikan kategorisasi pemuda dengan konsep yang diakui oleh negara. Sebenarnya penggunaan kata pemuda juga menjadi perdebatan tersendiri karena mulai mengalami pergeseran di dalam masyarakat Indonesia. Hal tersebut seperti yang dikemukakan oleh Parker \& Nilan bahwa sejak era reformasi, kata pemuda mulai tergeser menjadi remaja (2012:19). Oleh sebab itu kemudian peneliti menggunakan definisi anak muda yang lebih sesuai dengan kondisi riil di lapangan. Mereka yang berusia di dalam rentang 18-30 tahun lebih dikenal sebagai anak muda. Sementara pemuda lebih merujuk pada mereka yang telah berumur 20 tahun hingga 40 tahun an. Oleh karena itu kemudian peneliti lebih menggunakan padanan kata anak muda daripada pemuda pada penulisan kali ini. 
Penelitian ini dilakukan selama beberapa waktu pada masa pemilu legislatif hingga pemilu presiden 2014. Proses pengambilan data juga dilakukan beberapa kali setelah pemilu presiden usai. Menggunakan metode kualitatif, peneliti berusaha melihat dan menggambarkan dinamika pendidikan politik yang selama ini dilakukan dan dialami oleh para anak-anak muda di salah satu partai politik yang ada di Kota Malang. Tidak hanya itu peneliti juga berusaha memahami makna-makna yang terkandung dalam gerak gerik dan juga tindakan mereka selama berinteraksi dan beraktivitas. Pendekatan yang digunakan dalam penelitian kali ini adalah pendekatan biografi life story, dimana data masa lalu informan juga digunakan sebagai data untuk melihat masa kini (Bertaux,1988). Tentunya juga tidak hanya melihat informasi dari sisi subjektivitas informan semata, namun penting juga untuk melihat sistem sosial yang ada di lingkungannya (Ferrarotti, 1988:21-22). Oleh sebab itu, tidak hanya sekedar melakukan wawancara pada informan (anak-anak muda di dalam partai) saja, namun juga berusaha memperoleh data tambahan seputar informan pada lingkungan sekitarnya. Oleh sebab itu data masa lalu para informan tersebut menjadi pengantar untuk peneliti dalam memahami dan mengkaitkannya dengan aktivitas mereka di partai politik pada masa kini. Mengapa digunakan model penelitian ini tidak lebih untuk memperlihatkan realita anak-anak muda yang bergabung dalam partai politik. Apabila selama ini lebih berkaitan dengan elit, pada kesempatan penelitian kali ini akan lebih berfokus pada anak-anak muda yang bergabung dengan partai.
Setidaknya peneliti membedah tiga informan utama dalam keterlibatan mereka sebagai anak-anak muda di salah satu partai besar yang ada di Kota Malang. Partai tersebut dipilih karena sejak paska reformasi, bisa dikatakan memiliki massa/simpatisan yang solid sehingga secara tidak langsung basis massanya stabil dibandingkan dengan partaipartai lainnya. Ketiganya merupakan kaderkader muda yang cukup menonjol di partai tersebut yang terdiri dari dua perempuan dan satu orang laki-laki. Jadi dari sekitar kurang lebih 10 informan, konsep cerita kehidupan mereka lebih berwarna daripada informan lainnya. Hasilnya didapatkan ketiganya untuk penelitian kali ini. Dua srikandi tersebut bahkan mampu untuk masuk sebagai calon anggota legislatif dari dapil Kecamatan masing-masing. Oleh sebab itu peneliti kemudian turut dalam beberapa kegiatan mereka terutama selama pemilu legislatif dimana kader partai-partai politik saling bekerja untuk memaksimalkan potensi suara partai seperti dalam rapat di partai, kehidupan saat mereka bekerja/kuliah, bergaul dengan teman-teman mereka, hingga proses selama pemilu legislatif dimana mereka sibuk untuk berkampanye/mengkampanyekan tokoh partai mereka. Bahkan dapat dikatakan apabila partai politik terlihat lebih "hidup" pada masa-masa pemilu seperti pileg 2014 lalu. Penelitian juga berlanjut hingga pemilu presiden dimana ketiga informan juga memiliki asa untuk membantu calon presiden yang diusung oleh partai mereka memenangkan perolehan suara di wilayah Kota Malang. Proses analisis data dilakukan melalui reduksi data, penampilan data serta verifikasi dan proses kesimpulan (Miles \& Haber- 
man, 1992). Reduksi data digunakan untuk memilah data yang didapatkan dari ketiga informan tersebut dengan kesesuaian rumusan masalah yang dicari dalam penelitian kali ini. Se-mentara dalam penampilan data, peneliti mencoba untuk melihat hasil perbandingan dan persamaan di antara data para informan utama dan juga informan tambahan. Di akhir kemudian dilakukan verifikasi terhadap data secara keseluruhan sebelum akhirnya memunculkan kesimpulan dalam kajian kali ini.

\section{PEMBAHASAN}

\section{Anak Muda dalam Perspektif Kuasa Simbolik}

Sebagaimana yang telah dipaparkan pada sub bab sebelumnya dimana penggunaan kata anak muda dirasa lebih cocok daripada pemuda. Hal ini terutama terkait usia dari para informan yang menjadi semacam penanda biologis bagi mereka untuk dikategorikan sebagai pemuda maupun anak muda. Meskipun dalam beberapa perspektif yang dimotori oleh Mannheim menyebutkan bahwa usia bukan semata-mata penanda seseorang dikategorikan dalam sosok muda (1952; lihat juga Wyn dan White, 1997). Dalam beberapa kultur masyarakat usia masih menjadi penanda kategorisasi anak-anak, pemuda, maupun orangtua. Pun demikian dengan yang ada di partai pada kajian kali ini dimana usia masih tetap menjadi penanda sederhana dalam mengidentifikasi anak-anak muda.

Pendidikan politik merupakan sebuah bagian penting yang didapatkan oleh individu ketika bergabung dengan partai politik. Terlepas dari berita miring mengenai partai politik, partai tetap memiliki proses pembelajaran terhadap kader-kadernya mengenai mekanisme berpolitik dengan baik. Hal tersebut tentunya dikembangkan guna mencetak kader-kader yang handal dan mampu bersaing tidak hanya pada tataran internal partai namun juga eksternal di masyarakat. Oleh sebab itu melalui partai politik, kaderisasi generasi muda diperlukan selain untuk tetap meningkatkan jumlah kader yang berkualitas bagi partai.

Anak muda memiliki kebebasan dalam melakukan tindakannya dan berusaha untuk menentukan diri mereka dalam seting sosial dimana mereka berada (Margono, 2011: 3). Dalam konsep agensi, anak muda tidak hanya diatur oleh struktur yang ada di sekitar mereka. Para anak muda tersebut juga memiliki pilihan yang mereka ambil untuk kepentingannya. Meskipun lingkungan eksternal yang ada di sekitar mereka juga turut memberikan pengaruh dalam proses pengambilan keputusan. Anak-anak muda ini juga bisa menentukan pilihannya sesuai dengan apa yang mereka putuskan. Dalam penjelasan perkembangan anak muda, hal tersebut merupakan perpaduan dua sisi individual dan sosial ketika mereka memutuskan suatu tindakan (Wyn \& White, 1997). Hal tersebut yang nantinya akan membedakan antara individu muda yang satu dengan lainnya. Meskipun memiliki usia dan juga lingkungan sosial yang sama, tindakan yang mereka putuskan bisa berbeda-beda sesuai dengan kepentingan masing-masing.

Kritik yang muncul dari dikotomi tua dan muda juga muncul dalam penjelasan Bourdieu 'Youth' is just a word (1993). Bagi Bourdieu pembagian bentuk stuktur yang diklasifikasikan melalui umur merupakan logika kekuasaan yang berada di masyarakat. Seperti halnya kelas dimana terdapat dikotomi yang berbeda antara satu dengan lainnya. Bourdieu melihat hal tersebut sebagai bentuk dari manipulasi yang 
berkembang dalam masyarakat. Adanya dikotomi senior dan junior merupakan bentuk ketimpangan sosial yang terjadi dan merupakan konstruksi sosial dalam masyarakat. Anak muda kerap diletakkan dalam dua sisi yang berbeda apabila dilihat dari segi transisi yakni sebagai orang dewasa sekaligus anakanak pada sisi lain (1993:96). Bourdieu bahkan memberikan gambaran bahwa orang tua dalam beberapa hal memang memiliki modal yang lebih daripada anak-anak muda. Kecuali apabila keduana berasal dari kelas sosial yang berbeda dimana biasanya anakanak muda mendapatkan pewarisan modal ekonomi, sosial, budaya, dan simbolik dari orangtuanya masing-masing. Menurut Bourdieu orang lebih tua yang biasanya menolak dan menilai anak muda lebih lemah karena sudah tidak ada masa depan bagi mereka. Berbeda dengan anak muda yang masih memiliki masa depan apabila dilihat dari segi usia mereka (1993:100). Konsep-konsep tersebut yang kemudian mengawali peneliti untuk memfokuskan diri pada bagaimana anak-anak muda saling bersaing di bawah dominasi kader-kader senior di partai politik.

\section{Anak Muda Bicara dan Beraksi di Partai Politik}

Ketiga informan utama memiliki latar belakang yang berbeda-beda. Setidaknya hal tersebut pada akhirnya turut berimbas pada pilihan mereka untuk bergabung dengan partai politik. Pada sub bab ini akan men-jelaskan narasi mengenai bergabungnya mereka di dalam partai hingga pendidikan politik apa saja yang telah didapatkan. Pengalaman sekaligus aktivitas mereka selama di partai politik menjadi salah satu basis data bagaimana ritme dan dinamika kaderisasi sekaligus peningkatan kualitas kader partai. a) Ima, Ibu Rumah Tangga Berusaha Menggapai Kursi Legislatif

Ima merupakan salah satu caleg muda yang menjadi informan dalam penelitian kali ini. Lahir 29 tahun lalu, Ima mampu melanjutkan pendidikannya hingga jenjang perkuliahan. Bapak Ima bekerja sebagai kepala hansip di wilayah Kota Malang, sementara Ibunya di rumah sebagai ibu rumah tangga. Ia memulai jenjang pendidikannya di TK Dharma Wanita dan melanjutkan ke sebuah MTS (Madrasah Tsanawiyah). Usai itu, ia masuk SMPN 4 Kota Malang. Namun rupanya ketertarikannya pada sekolah agama membuatnya kembali memilih MAN (Madrasah Aliyah Negeri) 3 Kota Malang. Walaupun bukan berasal dari keluarga yang religius, Ima mengakui bahwa lingkungan sekolah di madrasah lebih nyaman daripada sekolah negeri. Oleh sebab itu kemudian ia melanjutkan pendidikannya di MAN. Hingga akhirnya 2003, ia masuk ke dunia perkuliahan di salah satu universitas negeri di Kota Malang.

Selama hidupnya, Ima cukup aktif terlibat dalam beberapa organisasi. Terlebih lagi Ima merupakan anak tunggal sehingga menurutnya berorganisasi adalah tempat untuk mendapatkan teman serta saudara baru. Saat SMP Ima aktif dalam kegiatan pramuka, sementara saat SMA ia terlibat dalam organisasi di luar sekolah yakni BKM PNPM. Ketertarikannya untuk ikut terelbih diorong oleh Bapaknya yang merupakan salah satu tokoh di wilayahnya sehingga rumahnya kerap dijadikan tempat untuk rapat BKM PNPM. 
"Dulu kan Bapak itu jadi salah seorang pengurus BKM Mas jadi rapatnya itu sering di rumah ini. Nah dari situ mulai belajar sama muda-mudi atau mas dan mbak mahasiswa buat belajar tentang pemberdayaan masyarakat. Memang di awal itu aku nggak benarbenar ikut bikin program Mas, tapi aku sudah mulai bantu-bantu seperti bikin catatan dan manajemen anggaran"

(Wawancara di Malang, April 2014)

Hingga akhirnya saat kuliah selain aktif di karang taruna Kota Malang, Ima tertarik untuk masuk pada partai politik. Awalnya Ima masuk ke dalam tingkatan anak ranting sebelum akhirnya masuk ke tingkat yang lebih tinggi. Kesigapannya dan pengalamannya selama bergabung dengan partai termasuk saat momen-momen pilkada membuatnya mulai mendapatkan kepercayaan dari pihak partai. Masa transisinya untuk mendapatkan pekerjaan pun berjalan lancar terlebih karena informasi lowongan pekerjaan yang ia dapatkan dari relasi di karang taruna. Ima kemudian bekerja di salah satu distributor merk kacang nasional sampai sekitar 2012. Kemudian pada sekitar akhir tahun 2012, Ima memutuskan untuk keluar dari pekerjaannya dan mencoba mencalonkan diri menjadi caleg partai. Ima sebenarnya mulanya masih gamang dengan keputusan mencalonkan dirinya sebagai caleg. Namun karena pekerjaannya sendiri masih sebatas dalam tahapan outsourcing, ia merelakan untuk berhenti dan fokus pada pemilu legislatif 2014.

"Awale ya bingung Mas mau milih ini (caleg) atau kerjaan. Tapi la aku sendiri kerja itu masih outsourcing Mas, akhirnya ya sudahlah aku milih ngelepasin pekerjaanku buat mencoba tantangan baru."

(Wawancara di Malang, April 2014)

Lantas bagaimana pendidikan politik yang didapatkan oleh Ima selama bergabung di dalam partai? Menurut Ima banyak penga- laman serta pengetahuan yang didapatkannya terutama pada saat pemilukada. Baginya partai politik yang sekarang dihuninya kurang memberikan pelatihan kaderisasi terutama pada para perempuan. Ia juga merasa beberapa acara kaderisasi yang diikutinya sepi dimana hanya beberapa anak muda dan salah satu kader struktural yang hadir. Alhasil acara peningkatan kualitas mutu kader dari segi social politik tersebut dihilangkan dari agenda DPC. Menurutnya hal tersebut juga terkait dengan pendanaan untuk acara yang minim dari DPC. Ima akhirnya tidak banyak berharap pada acara-acara peningkatan mutu kader dari partai. Ia lebih memilih untuk mencari pengalaman dari praktek langsung selama pilkada berlangsung. Dari pilkada setidaknya dia mendapatkan pengetahuan politik dari beberapa senior dan juga pengalaman lebih terkait kehidupan berpolitik.

"Kalau acara kaderisasi itu ya seperti yang sudah tak jelasin tadi Mas, kurang berkembang di partai. Aku dapet pendidikan politik itu ya pas momen pilkada Mas. Dari sana aku dapet banyak pengalaman terutama dari senior-senior yang maju (di pilkada). Mereka juga biasanya pas itu sering sharing ilmu Mas tentang dunia politik. Kalau nggak masa-masa itu kapan lagi Mas ketemu mereka, kan DPC kalua haribiasa sepi Mas"

(Wawancara di Malang, Mei 2014)

Dari beberapa pengalamannya tersebut akhirnya Ima memberanikan diri untuk mengikuti seleksi caleg di wilayah rantingnya. Karena pengalaman dan integritasnya di partai, Ima akhirnya terpilih sebagai salah satu caleg dari partainya. Bagi-nya hal tersebut cukup membanggakannya mengingat partainya merupakan salah satu par-tai besar tidak hanya di Malang namun juga di Indonesia. Ima juga menuturkan banyak be- 
lajar dari mengamati kader senior yang terlebih dahulu telah turun pada saat pemilu. Meskipun akhirnya gagal lolos pada pemilu legislatif 2014 lalu, Ima masih tetap berusaha bangun dari kegagalan. Baginya kegagalan tersebut justru memacu dirinya untuk giat maju pada kesempatan berikutnya sembari mengumpulkan ilmu dan juga dana finansial.

b) Sinta, Caleg Perempuan Termuda

Sinta yang lahir pada tahun 1991 lalu ini merupakan caleg termuda dari partainya. Dibesarkan oleh Bapak seorang tukang becak dan Ibu pedagang kelontong, Ima mampu untuk melanjutkan pendidikannya hingga jenjang perkuliahan. Kondisi keuangan keluarga yang kurang membuatnya harus mengambil pekerjaan paruh waktu selama SMA hingga kuliah. Meskipun sempat tidak langsung melanjutkan ke jenjang perkuliahan setahun paska lulus SMA karena terkendala pendanaan. Beruntung kini Kakak pertamanya yang bekerja di Bali cukup banyak membantu dalam mengatasi masalah keuangan keluarga.

"Dulu waktu awal kuliah memang masih sempat kerja di salah satu kantor konsultan pajak di Malang. Tapi terus tahun 2011 keluar dan jadi guru PAUD karena waktunya lebih fleksibel. Sekarang aku sudah nggak kerja di sana lagi dan lebih memilih fokus di pekerjaan biro wisata. Soalnya lebih menjanjikan masa depan dan finansial Mas"

(Wawancara Sinta, 1 Juli 2014)

Awal mula Sinta bergabung di dalam partai merupakan sebuah hal yang tidak disangka atau diimpikannya sama sekali. Terlebih lagi Sinta memang kurang peduli dengan hal-hal yang sifatnya politis. Namun karena di wilayah rantingnya tidak terdapat anak muda yang mampu menggunakan komputer dan mengatur serta menulis surat, ia kemudian dilibatkan. Sempat beberapa kali menolak dan bahkan hingga menghindar dan me- nginap di rumah temannya karena para kader di rantingnya selalu mendatangi rumahnya ketika diadakan rapat, Sinta akhirnya merasa kurangn nyaman dan sungkan pada kedua orangtuanya. Keduanya harus menghadapi kader-kader ranting partai yang cenderung memaksakan kehendak mereka. Akhirnya Sinta memilih untuk terlibat di dalam ranting kepartaian.

Sinta mengungkapkan tidak banyak pendidikan politik yang didapatkannya dari partai. Bahkan Sinta mengeluhkan bahwasanya kader-kader di wilayah rantingnya kerap hanya mencari tambahan financial semata dari partai terutama saat proses pemilu baik legislative maupun kepala daerah. Hal tersebut yang kerap membuatnya acuh padahal hal yang berhubungan dengan perpolitikan. Baginya politik tidaklah lebih dari permainan perebutan kekuasaan dan materi. Hingga akhirnya mendekati pemilu legislatif 2014, Sinta dipilih sebagai salah seorang caleg dari wilayahnya guna melengkapi kuota perempuan.

Awalnya Sinta menolak terutama karena baginya menjadi salah seorang caleg bukanlah keinginannya pribadi. Namun karena kuatnya tekanan kader-kader lain di wilayah rantingnya, Sinta akhirnya menjadi salah satu caleg perempuan di partainya. Untuk sebagian besar caleg yang mencalonkan diri, mereka rata-rata mengeluarkan dana yang jumlahnya tidak sedikit untuk mengakomodir pemilih sekaligus tim sukses masing-masing. Berbeda dengan Sinta yang memang sejak awal tidak menginginkan untuk maju dimana ia hanya dibantu oleh $\mathrm{Pa}$ man dan kedua orangtuanya. Untuk dana finansial kampanye dia dibantu oleh salah seorang kader senior yang cukup mapan di partainya, terutama untuk mencetak leaflet. 
Tidak hanya itu, Sinta juga mengaku tidak memiliki visi dan misi yang jelas. Baginya penulisan visi dan misi hanya sebuah formalitas belaka untuk mengikuti pemilu. Bahkan Sinta merasa semakin muak pada lingkungan kader-kader di wilayah rantingnya yang saling menjatuhkan satu sama lain dalam memperebutkan suara di ranah grass root. Hal yang baginya ironis sekaligus sebuah kenyataan bahwa dalam politik kawan pun akhirnya menjadi lawan. Bagi Sinta partainya terutama di wilayah ranting gagal memberikan pendidikan politik yang mumpuni dan berkualitas bagi kader-kadernya. Bagi Sinta acara kaderisasi yang biasanya dilakukan oleh DPC hanya sekedar acara kumpul bagi para kader. Muatan acara yang biasanya diisi dengan peningkatan kapabilitas dan kualitas pendidikan politik bagi kader hanya menjadi angin lalu dan pelengkap semata. Oleh sebab itu Sinta tidak terlalu mengambil pusing perihal pemilu legislatif. Justru ia merasa kerap tersakiti karena berita atau kabar miring yang kerap dilontarkan oleh kader-kader partai di ran-tingnya yang menjadi tim sukses dalam pemilu legislatif.

"Itu bener-bener bikin malu Mas nggak Cuma partai tapi juga diri mereka sendiri. Awalnya aku diminta dengan pujian-pujian biar mau jadi caleg perempuan. Eh kok pas waktu pemilu legislatif mereka malah sering bikin kabar miring tentang caleg-caleg di partai untuk mendongkrak popularitas caleg yang diusung. Kalo menurutku pendidikan politik di partai nggak mampu meningkatkan kualitas anggotanya Mas."

(Wawancara Sinta, Mei 2014)

c) Robi, Kader Mahasiswa Produktif

Robi merupakan satu-satunya informan laki laki sekaligus non caleg dalam penelitian kali ini. Meskipun bukan sebagai salah seorang caleg, namun Robi merupakan salah satu kader muda yang cukup menonjol. Tidak hanya selama peneliti melakukan penelitian lapangan, namun juga berdasarkan data yang dikumpulkan dari kader-kader lainnya mengenai Robi. Dilahirkan 27 tahun yang lalu, Robi merupakan mahasiswa jurusan Ilmu Politik di salah satu universitas di Kota Malang. Baginya ketertarikannya dalam hal politik tidak bisa dilepaskan dari masa lalunya yang sempat bersama dengan keluarganya pergi hingga Amerika untuk menghindari konflik pada masa reformasi 1998.

Dibesarkan oleh Ibunya, Robi mengaku cukup mengalami ingatan buruk perihal masa gejolak reformasi dimana Ia dan keluarga besarnya harus melarikan diri hingga Singapura. Kemudian Ibunya membawa Robi untuk tinggal di Amerika selama setahun hingga kondisi di Indonesia membaik. Sekembalinya ke Indonesia, Robi sempat tinggal di wilayah Ibukota untuk beberapa saat sebelum akhirnya Ibunya memutuskan untuk membangun kembali usahanya di wilayah Kota Malang. Terkait dengan berpindah-pindahnya ia hingga ke negara lain, Robi kerap bertanya pada Kakeknya mengenai gejolak-gejolak sosial politik pada masa itu. Jawaban yang diberikan oleh Kakeknya tersebut yang kemudian membuatnya cukup tertarik pada hal-hal yang sifatnya politis.

Namun Robi tidak langsung memberanikan diri masuk ke bidang perpolitikan secara langsung. Bahkan ia sempat vakum selama beberapa tahun untuk membantu usaha keluarganya di Jakarta sebelum akhirnya memutuskan masuk ke jurusan Ilmu Politik. Meskipun sempat dilengkapi penolakan dari Ibunya perihal pilihan jurusan yang diambil- 
nya, Robi tetap bersikukuh untuk masuk dan melanjutkan studi di sana. Baginya jurusan yang ia ambil saat ini merupakan passionnya.

"Sempet Mas itu Mama nggak sepakat sama pilihan saya untuk kuliah di jurusan ilmu politik. Ya mau gimana lagi Mas, keluarga saya kan rata-rata berwirausaha, jadi harapannya mereka biar saya ambil kuliah itu di bidang perbisnisan atau ekonomi yang berhubungan sama usaha Mama. Tapi itu udah jadi passion saya Mas ketika akhirnya memilih ilmu politik. Saya juga udah janji sama Mama dan keluarga bakal tetap bantuin usaha keluarga, sehingga akhirnya luluh dan diperbolehkan kuliah disana Mas."

(Wawancara Robi, Juli, 2014)

Dari masuknya dia ke jurusan ilmu politik membuatnya kemudian menginginkan pengalaman praktek secara langsung dengan bergabung di partai politik. Meskipun baru bergabung di partai, namun karena pengalamannya serta kesigapannya, mem-buatnya dipilih sebagai salah satu petinggi di organisasi kepemudaan partai. Bagi Robi melalui partai politik dia mampu mengaktualisasikan ilmu yang telah ia peroleh dalam ranah praksis, meskipun pada akhirnya tidak semua berjalan dengan cukup baik dan lancar.

Menurut Robi, keinginan kader baik muda maupun tua untuk mengembangkan kualitas dan kapabilitas diri guna peningkatan mutu partai masin rendah. Hal tersebut dirasakannya saat ia beberapa kali mengadakan agenda sekolah politik dengan mendatangkan aktivis, akademisi, dan juga kader partai yang mumpuni di bidang tersebut untuk menyalurkan ilmu mereka pada kader-kader partai. Alhasil hanya beberapa kader yang hadir di acara yang langsung diadakan oleh DPC tersebut. Pun demikian dengan pemilu legislatif 2014 lalu yang ia ikuti dimana Robi juga menjadi salah satu anggota tim sukses caleg DPR Pusat. Salah satu tujuan utamanya yakni untuk memperkuat basis suara partai sesuai yang diamanatkan oleh pimpinan pusat untuk menggalakan prosentase suara di tiap wilayah dari DPC hingga anak ranting. Hal tersebut yang kemudian membuat Robi terpacu untuk meningkatkan suara dari lingkungan sekitar dirinya. Ia merasa sudah sebagai kewajiban seorang kader partai untuk membantu meningkatkan popularitas sekaligus suara partai di akar rumput. Terlebih lagi bagi Robi, proses pileg ini merupakan suatu proses pembelajaran politik yang dialami dan dijalaninya.

Robi hanya memilih caleg untuk ia promosikan terutama karena simpati dan rasa kepercayaannya pada mereka. Awalnya Robi tidak terlalu tertarik dengan prosesi kampanye yang dilakukan oleh masingmasing caleg tersebut. Namun setelah mendekati masa kampanye para caleg di penghujung awal 2014, Robi mulai menyadari bahwa untuk masuk ke dalam tahapan selanjutnya, ia harus mengenal elit maupun caleg di partai. Hal tersebut terutama untuk meningkatkan "popularitas"nya di kalangan partai terutama di struktur DPC. Oleh sebab itu kemudian Robi dalam beberapa kali kesempatan, ikut mengkampanyekan caleg-caleg yang dipercayainya.

Di masa pemilu legislatif tersebut Robi menyaksikan bahwa politik itu tidak seindah sebagaimana yang dia bayangkan dalam buku maupun perkuliahan. Praktek di lapangan rupanya kerap berbeda dengan gambaran yang dibaca Robi selama kuliah. Baginya proses mencari kekuasaan dalam politik yang jujur dan bersih seakan-akan hanya menjadi utopia, ketika dia melihat bagaimana praktek-praktek yang dilakukan baik caleg maupun kader dalam meningkatkan 
popularitasnya. Namun akhirnya dia menyadari bahwa hal tersebut bukan sematamata kesalahan para caleg dan tim suksesnya, namun juga karena minimnya pendidikan politik di wilayah grass root. Oleh sebab itu kasus-kasus negatif di seputar pemilu selalu terulang kembali.

\section{Kuasa Simbolik Beda Generasi}

Pendidikan politik di partai rupanya masih belum berjalan secara efisien dan efektif. Para kader baik tua maupun muda rupanya masih enggan untuk belajar mengenai pendidikan politik yang diselenggarakan oleh DPC partai. Bagi kebanyakan dari mereka pendidikan politik didapatkan melalui pengalaman mereka langsung di lapangan terutama pada masa pemilu baik legislatif maupun pemilihan kepala daerah. Hal yang sebenarnya cukup ironis melihat masih kurangnya kualitas tingkat pemahaman politik mereka. Acara peningkatan pendidikan politik melalui program yang diselenggarakan oleh partai yang seharusnya menjadi basis ilmu bagi para kader justru dianggap sebagai luapan wacana semata. Hanya segelintir kader (terutama mereka yang berada pada usia muda) yang menyadari bahwasanya program pendidikan politik di ranah partai masih diperlukan. Minimnya kualitas pendidikan politik ter-sebut pula yang pada akhirnya turut berperan dalam hubungan antara kader senior dan junior. Meskipun dalam partai seharusnya semua kader memiliki kesetaraan yang sama (kecuali tentunya apabila melihat dalam konteks struktural jabatan di partai), namun nyatanya masih terdapat distingsi antara kader senior dan junior. Masih terdapat dominasi dari para kader senior bahkan bisa jadi sebuah hegemoni dimana para kader muda menelan mentah dominasi yang terjadi di partai sebagai sebuah keniscayaan. Hal tersebut ditunjukkan dalam beberapa kali pertemuan ataupun kesempatan dimana anak-anak muda tersebut tidak memiliki ke-sempatan untuk menampilkan atau menyuarakan pendapatnya. Pendapat yang disampaikan dalam forum seperti yang per-nah dilakukan oleh Ima dan Robi misalnya. Keduanya beberapa kali ikut bersuara dalam konteks rapat-rapat kebijakan DPC, namun alih-alih mendapatkan dukungan, pendapat mereka justru hanya menjadi angin lalu. Pendapat para tokoh senior lebih diutamakan karena dalam rapat tersebut menurut mereka pengalaman yang berbicara banyak daripada usul-usul baru dari para kader muda.

Perebutan kekuasaan di partai politik sebenarnya hanya berkutat pada lingkaran elit yang saling berusaha mendominasi partai. Hal tersebut sebagaimana diungkapkan Gary W. Cox dimana kemunculan partai sebenarnya pada dasarnya adalah keputusan elit politik untuk masuk sebagai kontestan dalam pemilu (dalam Marijan, 2012: 63). Hal yang ke-mudian menjadi lumrah di sistem partai politik Indonesia dimana para elit partai beserta jajarannya merupakan kader yang re-latif senior. Dalam penelitian kali ini peneliti memang tidak menemukan kader usia muda yang mampu menduduki jabatan strategis di sebuah partai politik. Hal yang kemudian kerap menjadi pertanyaan mengenai proses regenerasi partai politik di Indonesia yang berjalan pelan, karena ratarata memang diisi oleh kader senior, bahkan untuk ketua kaderisasi dan pemuda di DPC.

Sebagaimana penuturan dari narasi yang dijelaskan oleh ketiga informan utama dan juga hasil observaasi serta wawancara 
dengan beberapa kader yang lain, Partai politik sebagai sebuah ranah juga masih memperlihatkan adanya dikotomi senior dan junior di dalamnya. Anak-anak muda di partai memiliki kecenderungan diacuhkan, kecuali apabila mereka memiliki akumulasi modal yang sama dengan seniornya. Dalam partai politik, senior yang telah lama berkecimpung di dalam dunia politik tentunya juga telah memiliki akumulasi modal lebih agar bertahan hingga saat ini. Para orang tua di dalam tubuh partai memiliki posisi yang dominan dalam melanggengkan kekuasaan di partai. Doxa yang terbentuk biasanya juga merupakan konsolidasi elit yang berkuasa. Hal tersebut dapat dilihat dari struktur elit partai di tiap DPC, mayoritas diisi oleh orang-orang tua daripada anak muda. Pun demikian dalam kegiatankegiatan kampanye, para senior lebih memilih memberikan perintah pada mereka yang lebih muda. Akumulasi modal yang lebih besar menjadi salah satu cara bagi senior-senior di partai politik untuk melanggengkan dominasi tersebut. Anak-anak muda di partai beberapa lebih memilih diam, namun di sisi lain mereka juga secara sadar maupun tidak berusaha lepas dari dominasi semacam itu. Hal tersebut menjadi gambaran sisi lain anak-anak muda yang dikaji saat masa pemilu legislatif 2014.

Sebagai contoh bagaimana dominasi kader senior mampu memberikan "perintah" bagi anak-anak muda agar berjalan sesuai amanat partai. Penggunaan kata amanat partai merupakan bentuk perintah secara tidak langsung yang dikelola dan dirembug oleh kaderkader senior agar dilaksanakan oleh anakanak muda di partai. Hal tersebut terjadi pada konteks Sinta yang harus rela menjadi caleg dari wilayah dapilnya karena kurangnya kuota perempuan. Tidak dapat dipungkiri bahwa posisi Sinta sejak awal masuk ke dalam partai merupakan sebuah paksaan yang dilakukan oleh kader-kader rantingnya agar Sinta menjadi sekretaris di partai. Hal pertama yang menjadi alasan kenapa Sinta harus patuh pada amanat partai adalah karena dia perempuan. Hal yang dalam beberapa kesempatan mendapatkan kritik tajam dari Bourdieu terutama terkait masalah kesetaraan gender dimana otoritas yang berlaku di masyarakat biasanya merupakan bentukan lakilaki sehingga mereka akhirnya menjadi pihak dominan (Haryatmoko, 2003). Alasan kedua adalah karena dia anak muda yang (lagi-lagi) harus mematuhi doxa yang berlaku dimana amanat partai (oleh kader-kader senior) harus dijalankan. Alasan berikutnya adalah minimnya modal yang dimiliki oleh Sinta sehingga ia tidak memiliki posisi tawar yang sebanding ketika proses penunjukkan tersebut.

Pun demikian yang terjadi pada Robi dimana mereka harus menjalankan apa yang diamanatkan oleh partai. Robi mengutarakan bahwa partai sering memintanya untuk menjadi petugas protokoler saat upacara atau acara di DPC. Walaupun ia tidak menginginkannya, ia tetap harus berke-wajiban mematuhinya. Kurangnya kepemilikan modal yang dimilikinya dibandingkan dengan kader yang lebih senior membuatnya harus menjalankan amanat yang diberikan. Begitu pula dengan Ima yang kerap diminta untuk mewakili rantingnya sebagai perwakilan da-lam rapat di DPC. Sebagai anggota yang cukup muda, mau tidak mau Ima harus mewa-kili rantingnya walaupun terkadang akhirnya mesti mengganggu aktivitasnya. 


\section{KESIMPULAN}

Anak muda masih menjadi salah satu harapan bukan hanya di partai politik namun juga dalam kehidupan dan keberlangsungan masyarakat. Tentunya diperlukan proses pembelajaran serta pengalaman bagi mereka kaum muda untuk dapat tetap meningkatkan kualitasnya selama berada di partai politik. Meskipun minim kegiatan pembelajaran pendidikan politik di partai, hal tersebut tidak menyurutkan semangat mereka untuk tetap bertahan dan berjuang di ranah partai. Pun ditambah lagi dengan masih adanya dikotomi senioritas di tubuh partai yang semakin menyudutkan anak-anak muda tersebut dalam meningkatkan karir politik mereka. Kehidupan perpolitikan yang dilalui oleh anak muda memang penuh dinamika. Selain mesti berkumpul dengan keluarga dan temantemannya, para anak muda di partai politik juga masih berkecimpung dan aktif di partai politik. Sebuah keputusan yang pada akhirnya membuat mereka memiliki ranah berbeda-beda dalam kehidupan mereka.

Partai politik justru kerap menjadi ajang dominasi bagi para elit dan kader senior lain dalam hal perebutan status dan kekuasaan di tubuh partai. Terlebih dengan ke-pemilikan modal-modal penting yang dimiliki oleh para elit partai semakin mempertajam distingsi antara mereka dengan anak-anak muda partai. Mereka kaum muda hanya menjadi bagian dari kuasa simbolik yang dimilik oleh elit partai. Maka tak heran apabila anak-anak muda tersebut hanya bung-kam dan menunggu hingga generasi mereka mulai menjadi bagian penting di partai. Tentunya hal yang dikhawatirkan adalah pada akhirnya muncul alur kekerasan simbolik pada generasi yang lebih muda. Sebuah konsekuensi yang semes- tinya segera ditindaklanjuti sebagai sebuah pembelajaran politik bahwasanya anak-anak muda yang nantinya menjadi generasi pengganti akan mampu membangun dunia perpolitikan dengan lebih baik daripada saat ini.

\section{DAFTAR RUJUKAN}

Abdullah, Taufik. (1974) Pemuda dan Perubahan Sosial. Jakarta:LP3ES

Anderson, Ben. (1988) Revolusi Pemuda: Pendudukan Jepang dan Perlawanan di Jawa 1944-1946. Jakarta: Pustaka Sinar Harapan.

Azca, M. Najib, Subando Agus Margono, Lalu Wildan (editor). (2011) Pemuda Pasca Orba, Potret Kontemporer Pemuda Indonesia. Yogyakarta: Yousure.

Bourdieu, Pierre \& Louic J.D. Wacquant. (1992) An Invitation to Reflexive Sociology. Great Britain: Polity Press

Bourdieu, Pierre. (2011) Choses Dites, Uraian dan Pemikiran. Terj, Ninik Rochani Sjams. Yogyakarta:Kreasi Wacana.

------. (1995) Outline of A Theory of Practice. Trans, Richard Nice. Great Britain: Cambridge University Press.

-----. (1998) Practical Reason: On The Theory of Action. California: Stanford University Press.

------. (1990) The Logic of Practice. USA: Stanford University Press.

Daniel Bertaux (editor). (1988) Biography and Society: The Life History Approach in the Social Sciences. California, London: Sage.

Elder, Glen. (1988) History and Life Course. Biography and Society: The Life History Approach in the Social Scien- 
ces, pp 77-115.

France, Alan. (2007) Understanding Youth in Late Modernity. New York: Open University Press

Furlong, Andy \& Fred Carmel. (1997) Young People and Social Change, New Perspective. Open University Press

Haryatmoko. (2003) Menyingkap Kepalsuan Budaya Penguasa, Landasan Teoritis Gerakan Sosial Menurut Pierre Bourdieu. Basis No 11-12, Tahun 52, pp 4-23.

Hasibuan, Muhammad Umar Syadat. (2008) Revolusi Politik Kaum Muda. Jakarta: Yayasan Obor Indonesia.

Ichlasul, Amal (editor). (2012) Teori-Teori Mutakhir Partai Politik. Yogyakarta: Tiara Wacana.

Katz, Richard. S \& William Crotty. (2014)

Handbook Partai Politik. Bandung: Nusa Media

Marijan, Kacung. (2012) Sistem Politik Indonesia, Konsolidasi Demokrasi Pasca-Orde Baru. Jakarta: Kencana.

Mannheim, Karl. (1952) Essay on The Sociology of Knowledge. New York: Oxford Universiy Press.

Parker, Lyn \& Pam Nilan. (2013) Adolescents in Contemporary Indonesia. London, New York: Routledge.

Ricklef, M. C. (2008) Sejarah Indonesia Modern 1200-2008. Penerbit Serambi.

Rusdiarti, Suma Riella. (2003) Bahasa, Pertarungan Simbolik dan Kekuasaan. Basis No 11-12, Tahun 52, pp 31-40.

Salviana, Vina Darvina Soedarwo \& Wahyudi. (2015). An IntegrativeParticipative Model for Streghtening Knowledge and Political Education to
Cadres and Constituents of Political Parties. Research of Humanities and Social Sciences Vol 5 No. 82015

Swartz, David. (1997) Culture \& Power, The Sociology of Pierre Bourdieu. Chicago: The University of Chicago Press.

Wyn, Johanna \& Rob White. (1997) Rethinking Youth. Australia: Allen \& Unwin Pty Ltd 